\title{
eGaming? Seriously! for Information Literacy
}

\author{
Dr. Lesley Farmer \\ California State University Long Beach \\ 1250 Bellflower Blvd., Long Beach CA 90840 \\ USA \\ Lesley.Farmer@csulb.edu
}

\begin{abstract}
Schools and libraries are considering the incorporation of egaming because of its attraction to youth and its potential benefit for instruction, developing information literacy skills, and facilitating academic success. Although egames are played by most youth, egaming has gender-linked properties, particularly in novice gaming practice. School libraries are uniquely positioned to provide resources and services to insure gender-equitable gaming experiences: gaming periodicals, opportunities to select and review games, collaboration with classroom teachers, and game development. The emerging trends of casual gaming, mobile egaming, and gaming design offer opportunities that attract an ever broader range of students, which teacher librarians can leverage in their services.
\end{abstract}

Key Words: Egaming, gaming, school libraries, information literacy, mobile learning

\section{Introduction}

Gaming in school libraries? Be it board games or computer games, such activities have drawn great attention in the professional field. The American Library Association now has a gaming round table (http://www.ala.org/gamert), which sponsors events and shares resources about game programming in libraries. Where K-12 settings used to ban any games on the Internet and eschewed collecting game guidebooks, teacher librarians (TL) are now reconsidering their policies, holding gaming tournaments, and locating core gaming collection lists to help them purchase viable titles and even equipment (Nicholson, 2007). Not every school library is jumping on the band wagon, but the library world is certainly talking about gaming as evidenced in the American Association of School Librarians (AASL) September 2011 issue of its journal Knowledge Quest, with its theme of educational gaming.

Just a couple of decades ago, these same school libraries were addressing the issues of cardboard games (Levine, 2006). Of particular interest now are egames: video, console, and computer games, although those physical board and card games have experienced as resurgence as well. The movement of "gamification" has impacted educational practice overall with its focus on using game theory and game mechanicis to engage learners (Horizon Report, 2012).

For this paper, the term "egaming" will be used to differentiate these electronic forms of games from their more traditional print counterparts. While egames technically predated web 2.0, the convergence of Internet interactivity and increasingly popular MMORPGs (Massively Multiplayer Online Role Playing Games) has led to an almost inevitable consideration by TLs. Rather than fight the technological flood, TLs are trying to figure out ways to embrace the phenomenon. A certain "cool-ness" factor has played a part in this endeavor to show that school libraries can provide recreational options as well as academic. Some TLs "translate" egaming skills into information literacy skills to help students bridge life at school and at home. Furthermore, as 
education is increasingly incorporating serious games (that is, games that are not developed with the sole intent of entertainment, but also have educational or other communication objectives), TLs have an opportunity to collaborate with classroom teachers to locate and use serious games effectively for academic success.

\section{Background}

As noted above, egaming includes a variety of digital formats: video, console, portable game devices, cell phone, and computer-based. Additionally, several genres of games exist. In their study of teen gaming, Pew Internet \& American Life Project (2007) classified fourteen genres that teens play in order of preference: racing, puzzle, sports, action, adventure, rhythm, strategy, simulation, fighting, first-person shooting, roleplaying, survival horror, MMOG (massively multiplayer online game), and virtual worlds.

\section{Current Egaming Practice}

At this point, egames have substantially penetrated U. S. households, particularly since almost any device with a screen can support egames, A 2013 Pew Internet study indicated that 93 percent of teens go online, over ninety percent have access to computers at home, and three-quarters access the Internet on mobile devices (Madden, Lenhart, Duggan, Cortesi, \& Gasser, 2013). As far back as 2001, the National Institute of Media and Family found that practically all children either played egames or knew someone who did. The 2008 Pew study on video games and teens found that almost all teens play egames, that half played "yesterday." Usage by format was: 86 percent played on consoles, 73 percent played on desktop/laptop computers, 60 percent play on a portable gaming device, and 46 percent played on a cell phone or equivalent. The Civic Engagement Research Group study on teen gaming found that 97 percent played video games, about three-quarters played weekly, and a third played at least once a day. Moreover, eighty percent play at least five genres of games. The largest growth was seen in casual gaming and mobile use.

\section{Gendered Egaming Practices}

Gender plays a role in youth's gaming activity, mainly among novice teen girls. In her synthesis of gender issues in gaming behaviors, Agosto (2004) asserted that as girls enter adolescence their egaming activity drops in frequency. More specifically, Agosto found that teens start to explore their sexual identity, and egaming connotes masculinity, even in light of women gamers. In addition, Cooper and Weaver (2003) claimed that males and females tended to master egames differently. In terms of the physical experience, boys enjoy mastering complex hand-eye coordination itself, while girls prefer to focus on concrete goals; if the navigation protocols are difficult to figure out or distract from achieving the goal, girls are likely to walk away from the egame. On the other hand, Forsell (2008) observed that when girls find satisfaction accomplishing a gaming goal, they will continue to game, just as boys do; however, if girls have negative first experiences, they are less likely to become successful longterm gamers. Successful gamers of both sexes enjoy the sense of community and socialization, like to compete against themselves or to meet a goal, and like to explore virtual environments (Moline, 2010;Taylor, 2003).

Mobile devices seem to be more inviting and less threatening for girls, and girls play egames on these smaller devices eagerly, as seen as far back as a 2001 study by Schaumburg. The researcher found that girls' ability and self-confidence increased more than boys did because girls had time to practice regularly in school with this equipment. In explaining this phenomena, Hooper, Fitzpatrick and Weal (2007) asserted that girls were more likely than boys to initiate discussion and sharing of information, the features of mobile devices assist multiple perspectives and relationship-rich learning. These studies point to the benefits of supporting mobile 
devices in school settings, such as the library, in order to offer a non-threatening way to experience egames.

\section{Choice of Egames}

U. S. computer and video game software sales topped 16.6 billion dollars in 2011, with another eight billion dollars spent on hardware and accessories. Over a thrid of the games were rated $\mathrm{E}$ for Everyone, and only a quarter were rated $\mathrm{M}$ for mature (Entertainment Software Association, 2012). Youth have tens of thousands of titles to choose from. When exposed to a variety of game genres, boys and girls preferred adventure games overall. Likewise, both sexes enjoy role-playing games (RPGs) and simulations such as Final Fantasy (Square Enix) and Sims (Electronic Arts). These genres actively engage students, provide both textual and visual cues, often require collaboration in order to accomplish a task, often demand clear communication, can facilitate problem-solving skills, provide immediate feedback, and foster attention to detail (Gros, 2003). Physical games such as Wii and music-related titles also engage both sexes as they leverage kinesthetic learning style and reinforce personal improvement (McCann, 2008). Joseph and Kinzie (2005) identified five gaming modes that middle schoolers enjoyed: active, explorative, problem-solving, strategic, social, and creative.

Several studies explored the kids of egames that girls enjoy - or shy away from. Most egame motifs tend to be competitive, and many are combative, both of which stress girls but help boys manage anger (Lucas and Sherry, 2004). Nor do girls like intense problem-solving or high-stakes risks; they would rather explore an open-ended setting (Hayes, 2005). In Kafai's 1996 study, girls self-reported that ideal games have userfriendly interfaces, are challenging yet fun, encourage goals that can be quickly accomplished using logic, foster relationships, and mesh concrete characters and locales. Graner Ray (2004) asserted that one aspect of gaming that bothers females in general is the appearance of the characters or avatars, which tend to reflect masculine stereotypes, and feature fewer female variations. For that reason, girls tend to favor animal characters. It should be noted that the presence of "pink software," games targeted to girls, often reinforce female stereotypes (John, 2009). In addition, the concept of girl games itself raises the issue that such games are not the norm, the default option, thus marginalizing girls.

Casual games constitute a special subset of egames; they are used to relax, socialize, or achieve goals or challenges, and are seldom violent. The gaming industry has increased focus on developing these games for mobile devices. These platforms dictate the egame characteristics: constrained and low-resolution graphics, minimal text, easy to learn and basic controls, little set-up, and consumable in a short time period. Females make up the largest segment of mobile casual gamers (Entertainment Software Association, 2012).

Because of the nature of most egames, and girls' less frequent gaming behavior, girls are likely to be disadvantaged if egames are summarily introduced into school library settings (Agosto, 2004). Furthermore, according to the 2000 study of the American Association of University Women, if girls do not use computers by sixth grade, they are likely never to pursue science or technology. Therefore, TLs need to pay attention to individual students' experiences and interests if they are to insure that egaming is to benefit the school community. Fortunately, the gaming gender gap is closing; instead, TLs can focus on incorporating egames that either appeal to both sexes, or providing choices of games that speak to individual interests and needs. 


\section{Benefits of Egaming}

Certainly, egames attract and engage youth, sometimes even to the detriment of academics. On the other hand, egames reflect 21 st century literacy skills: information literacy, multimedia manipulation, creative problem solving, collaboration, and effective communication (Gee, 2007; Horizon Report, 2012).

In terms of learning theory, gaming as a learning mechanism is usually associated with activity theory. The basis of activity theory posits a relationship between a subject (person) and an object, with mediational means. Tools also mediate between the individual and the larger culture. Vygotsky and Luria (1994) focused on analyzing tasks that required the use of a goal-directed, mediated/cultural process. Leontev (1978) viewed activity on three levels: the activity itself, the level of actions, and operations (which tended to be "automatic" or fluent). Engestrom (1987) expanded this model to acknowledge the collective nature of human activity. Good game designers follow Vygotsky's zone of proximal development: providing a challenge (not just routine operations) that can feasibly be met (i.e., the outcome is doable), and that build on community effort.

In sum, games offer a rich learning environment in which to explore and achieve specific goals (Horizon Report, 2012). The following activity theory-based characteristics of gaming inform teaching and learning:

- use of fixed, equitable rules

- clear roles and expectations

- internally-consistent environment where everything is possible

- clear goals within a rich context that gives goals personal meaning and relevance

- opportunities to explore identities

- cognitive, affective, and social engagement

- (usually) multiple ways to achieve them through constructivist strategies

- specific, timely feedback

- sense of control and personal investment

- situated learning

- sense of reward for effort, including trial and error

- structured interaction between players, and between players and the game

- opportunities to develop imagination

- blend of cooperation and competition (DeKanter, 2005; Deubel, 2006; Gee, 2007; Sanford, 2008; Simpson, 2005; Squire, 2006; Lee \& Young, 2008).

It should be noted, as with other tools, egames of themselves will not guarantee effective learning. Egaming, specifically game simulations, incorporate gaming design into the knowledge building process rather than simply providing a way to organize information (Halverson, 2005). This kind of structural interactivity may be intimidating to teachers, who must overcome a "certain fear factor" in order to embrace video games in the classroom (DeKanter, 2005). Squire (2006) showed that many students find games more difficult than school; contemporary pedagogical practice creates "learned helplessness" by providing students with short, solvable problems with all information laid out. Game-based learning, on the other hand, begins with failure; students must build skills and knowledge over time by accessing new information, evaluating circumstances, and through practice (Gee, 2007; Squire, 2006). On the other hand, some educators welcome a learning approach that actually acknowledges the benefits of failure (Horizon Report, 2012). 


\section{Games in School Libraries}

School library mission statements most often include support of the school and district's curriculum initiatives, promotion of a love of reading and learning, providing access to quality resources, and developing efficient and effective users of information. In carrying out these missions, TLs are increasingly reaching out to their audiences more pro-actively, meeting them on youth's territory. TLs are trying to encourage nontraditional reading matter, such as graphic novels, elevated from their less valued comic book status. Likewise, gaming books have been successfully incorporated, and some TLs are providing egame access, hoping that youth will choose positive participatory leisure habits, including selected egames such as Dance Dance Revolution (Konami), Minecraft, and City of Heroes (NCsoft) (Neiburger, 2007). Especially as gamification is making inroads into educational settings, there is a need for more school library programs to reflect the ways in which exemplary school programs are using students' recreational interests to develop skills that will transfer to academic achievement, engage them in the school community, and encourage them to pursue information for personal gain and enrichment.

In a survey of 78 school libraries, Nicholson (2008) found that while 51 percent allowed web-based games on library computers, and 37 percent allowed locally-installed games to be played, 33 percent allowed no games at all in the school library. The school libraries participating in Nicholson's study had a wide variety of goals for their gaming programs, including: attracting new patrons, serving existing patrons, creating a school community hub, recognizing the cultural significance of games, allowing users to hone skills, raising funds, addressing new literacies, and keeping patrons occupied.

Jenny Levine's 2006 case study of a Downers Grove High School gaming event (which included board games as well as video games) showed that, for students who do not value the traditional services of the school library, gaming events provided a way for them to reconsider the library as a place that offers series that are sensitive to their personal worlds. In many cases, library patrons who show up once for a gaming event return to the library later for other non-gaming services (Nicholson, 2008). Neiburger and Gullett (2007) pointed out that gaming events at the library can offer players benefits that are more positive than could be experienced at home, thus making a social event out of their video game consumption, and potentially providing them with a community to which they can belong.

Student gamers already belong to an affinity space, defined by Gee (2007) as a space where people interact because of a common endeavor. Student gamers interact while playing egames; by reading gaming magazines, blogs, or websites; by discussing games; by drawing gaming characters on their notebooks; and by making references to games in classroom discussions. In addition, gaming opens communication between teachers and students (Simpson, 2005). When students are allowed access to egame-related services in the library, they are entering a portal to their egaming affinity space where they can interact, socialize, learn, and contribute to a larger information-based community (Gee, 2007).

The library can serve as a curriculum neutral yet resource-rich physical space where the entire school community can interact based on common interests. To that end, school libraries can optimize the physical library facility as a gaming affinity space in several ways:

- providing enough space at each computer station to allow two people to sit together

- allowing students to play games that build on social interaction, such as RPGs 
- offering a online venue to play RPGs so that gamers of different ages and sexes can interact safety and anonymously

- providing a venue for reviewing egames and sharing egaming experiences

- providing gaming-related information via the library web portal (e.g., under "new books," "reviews," "webliographies," "local resources")

- providing a venue for designing egames.

\section{Choosing Games}

Developing the library collection to include the recommended gaming resources offers another point of access for students to gain entry to the library's wider services. The following recommendations can help TLs develop the library's egaming collection:

- Add console-specific 'official' gaming magazines to the periodical collection

- Add gaming strategy guides to the general collection

- Add student-created content, such as game reviews, to the library website

- Add game-related displays that include game art, game-related fiction, and information about careers in gaming (girls can participate in this endeavor by suggesting resources, writing reviews, and creating displays).

Some games are for enjoyment alone, which is fine, but libraries are more likely to invest time and money in serious games, those that have other purposes than entertainment, since the library's collection needs to support the school's curriculum first and foremost. Fortunately, many commercial off-the-shelf (COTS) game satisfy that requirement. Several game publishers focus on the K12 market: Riverdeep's family of brands, Leapfrog, Scholastic, FableVision, and Brighter Minds Media. It is important to note that in order to be engaging to students, games should be both fun and interactive. Several good bibliographies serve as starting points for selecting games:

http://gaming.ala.org/resources/index.php?title=Main_Page

http://www.socialimpactgames.com

http://www.gamesparentsteachers.com

http://www.clrn.org

http://seriousgames.ning.com/

http://www.gamesforchange.org/

http://guides.masslibsystem.org/content.php?pid=338752

TLs might also consider acquiring game-creation application software, which is another method that classroom teachers have been using to foster literacy. When students create their own egames, they ramp up their own skill set, drawing upon their knowledge of egaming protocols and applying them to new settings (Tang \& Hanneghan, 2011). With the expansion of mobile gaming, apps for creating even more $\mathrm{m}$-games are starting to appear. Daley (2011) detailed the engagement and success that the school library's teens experienced when creating games using the programming tools Scratch and Alice.

\section{Information Literacy and Gaming}

Seeing the library as an access point to a gaming affinity space provides an opportunity to engage students in the practice of information literacy skills, specifically. Parallel to information literacy, games establish an information goal, require the user to locate resources, evaluate them, and move towards the goal by using found information (Simpson, 2005). Students involved in gaming must actively participate in decoding and manipulating language as they play the game Prospero's Island (MIT), for instance (Squire \& Jenkins, 2003) and to other highly involved games such as 
Civilization (Take-Two); the games act as a gateway to the search for further knowledge on a particular subject.

Egames require the use of information tools, collaboration, and trial and error (Simpson, 2005; Squire \& Jenkins, 2003; Gee, 2007) as well as promoting constructivist learning environments (DeKanter, 2005). Egames provide contexts for peer-to-peer teaching and emergence of learning communities (Squire \& Jenkins, 2003); students consult peers and guides (print and non-print) to help them be successful in their gaming efforts. Nicholson (2008) noted that games promote critical thinking skills, logic, and planning: all components of information literacy, if not traditional content-area curriculum. Students involved in gaming may access hints, tips, codes on the Internet, post reviews or experiences, or create game-related drawings (Prensky, 2006), all of which require a variety of information literacy skills. Acting at a higher level of information literacy, Gee points out that players start to overtly realize that their choices in their gaming reflect their behaviors in real life, and they begin reflecting on and questioning those real life choices (Gee, 2007). Gamers also enable youth to gain expertise in learning in informal educational settings (Moline, 2010).To the degree that TLs can explicitly align egame functions with information literacy, girls will see the academic "pay off" for egaming involvement.

Information literacy is in many ways aligned with gaming literacy, and the library program can offer instruction and guidance, both formally and informally, for students already involved with these literacies. To embed information literacy into gaming activities in an informal manner, the library program should provide students regular opportunities to collaborate in order to produce shared information about games, such as Frequently Asked Questions, game reviews, and game guides published on the library website. Such sharing of information benefits girls in particular because it builds on their language/communication strengths, and gives them an opportunity to become experts, which can raise their self-esteem.

\section{Egames and Library Instruction}

Instruction can intersect with egaming in a couple of ways: 1) linking personal egaming interest and skill to information literacy; 2) incorporating egames in learning activities; and 3 ) using egaming elements in instruction.

TLs seldom teach extensively as an independent teacher; they are more likely to teach one aspect of a class project, such as evaluating sources or organizing information. When serious games are incorporated into the curriculum, TLs can collaborate with the classroom teacher throughout the instructional design process:

- evaluating, selecting and testing appropriate games to meet specific student learning outcomes

- addressing technical issues associated with the game (e.g., installation, licensing, networking)

- determining and addressing pre-requisite skills students need to use the game successfully

- determining when and where (including the library) students will play the game

- incorporating information literacy into gaming activities (e.g., search strategies, evaluation of information, researching the game content context, communication of information)

- developing learning activities that link with the game (e.g., assuming roles, journaling game play, collaboration)

- assessing student learning in consort with gaming (Van Eck, 2008) 
TLs can also conduct research for the school on serious games and curriculum integration, and present the findings at curriculum development meetings and inservice development sessions.

TLs usually do not have the luxury of spending several periods over a week or more on an extensive game. However, casual games such as word games or referencerelated games might be successfully incorporated into a library lesson. Moreover, the elements of gaming - such as exploratory activity, collaborating with peers, and situated learning—can comprise much of library instruction.

Regardless of the level of instruction, current practices need to change to accommodate gaming students. To make the transfer of learning more effective requires that educators find out how students spend their time outside of school hours and how they self-identify their literacies (Alvermann et al., 2007). For example, students may be seeking information and problem-solving within the community but may be bored at school, seeing no relevance in what or how they are being asked to learn. By "translating" egaming behaviors such as asking expert advice or persevering until success is achieved into academic competences, TLs and other educators are acknowledging and leveraging students' personal expertise as it applies to their formal learning environments.

\section{Library Issues in Egaming}

Even though egaming can benefit the school community and draw more students in the library, integrating egames in the library program can be problematic. On an administrative level, TLs must determine the place of egames within the library program as a whole. How does egaming contribute to the library's mission, and how does it align with the school's charge? TLs might not have the funding to acquire the needed equipment, or may be questioned about their spending priorities if they buy a Wii system instead of a laptop computer or encyclopedia. To solve this problem, TLs sometimes borrow systems from public libraries or school community members. They seek material donations and apply for grants, such as the American Library Association's gaming initiative.

Allocation of resources extends to the games themselves. In that respect, online games are more attractive for several reasons: no software is involved to be installed or maintained (or stolen), more students can access the game simultaneously, equipment is usually already present, and Internet connectivity is usually in place. With the explosion of free mobile device applications (apps), TLs might consider creating a webliography of curriculum-related apps that school community members could download. Of course, such file transfer has to comply with school technology use policies and procedures.

Nevertheless, Egaming speaks volumes about youth. It also signals a need to systematically gather data about the incorporation of egaming in school libraries to determine its impact on learning and personal growth. Egaming can address student awareness of and affinity for information literacy skills related to collaboration, pursuit of personal interests, evaluation of information, and information sharing. Existing egaming practices provides the library program a point of entry to engage students in leveraging their personal skills for academic success.:

\section{References}

Agosto, D. (2004). Girls and gaming: A summary of the research with implications for practice. Teacher Librarian, 31(3), 8-14. 
American Association of University Women. (2000). Tech-savvy: Educating girls in the new computer age. Washington, DC: American Association of University Women.

Cooper, J., \& Weaver, K. (2003). Gender and computers: Understanding the digital divide. Nawah, NJ: Erlbaum.

Daley, M. (2011). Using video games to embrace inquiry. KnowledgeQuest, 40(1), 6669.

DeKanter, N. (2005). Gaming redefines interactivity for learning. TechTrends, 49(3), 26-31.

Deubel, P. (2006, Jan.). Game on. T.H.E. Journal, 30-41.

Engeström, Y. (1987). Learning by expanding: An activity-theoretical approach to developmental research. Helsinki, Finland: Orienta-Konsultit.

Entertainment Software Association. (2012). Game player data. Washington, DC: Entertainment Software Association.

Gee, James. (2007). What video games have to teach us about learning and literacy $\left(2^{\text {nd }}\right.$ ed.). Palgrave, England: Macmillan.

Graner Ray, S. (2004). Gender inclusive game design: Expanding the market. Hingham, England: Charles River Media.

Gros, B. (2003, July). The impact of digital games in education. First Monday. Retrieved from http://www.firstmonday.dk/issues/issue8_7/xyzgros/

Halverson, R. (2005). What can K-12 school leaders learn from video games and gaming? Innovate, 1(6). Retrieved from http://www.innovateonline.info

Hayes, E. (2007). Women, video gaming \& learning: Beyond stereotypes. TechTrends, 49(5), 23-28.

Hooper, G., Fitzpatrick, G. \& Weal, M. (2008). Does it matter who is holding the PDA in a mobile learning experience? In JADíS International Conference of e-Leaming. April, Algarve, Portugal.

Horizon report. (2012). Austin, TX: New Media Consortium.

John, T. (2009). Ridiculous life lessons from new girl games. Wired (July 13). Retrieved from http://www.wired.com/gamelife/2009/07/games-for-tweens/

Kafai, Y. (1996). Video game design by girls and boys: Variability and consistency of gender differences. In J. Cassell \& H. Henkins (Eds.). For Barbie to Mortal Kombat: Gender and computer games (pp. 90-114). Cambridge, MA: MIT.

Lee, J., \& Young, C. (2008). Middle level educators and online social gaming. In K. McFerrin, et al. (Eds.), Proceedings of Society for Information Technology and Teacher Education International Conference 2008 (pp. 1726-1732). Chesapeake, VA. American Association of Computer Education. 
Leont'ev, A. (1978). Activity, consciousness, and personality (M. J. Hall, Trans.). Englewood Cliffs, NJ: Prentice Hall.

Levine, J. (2006). Gaming and libraries. Library Technology Reports, 42(5).

Lucas, K., \& Sherry, J. (2004). Sex differences in video game play: A communicationbased explanation. Communication Research, 31(5), 499-523.

Madden, M., Lenhart, A., Duggan, M., Cortesi, S., \& Gasser, U. (2013). Teens and technology 2012. Washington, DC: Pew Research Center.

McCann, S. (2008). Not just for boys anymore. Library Journal, 133(13), 51.

Moline, T. (2010). Video games as digital learning resources. School Libraries Worldwide, 16(2), 1-15.

National Institute on Media and the Family. (2001). $11^{\text {th }}$ annual mediawise video game report card. Minneapolis: National Institute on Media and the Family. Retrieved from http://mediafamily.org/research/report_vgrc_2006.shtml

Neiburger, E. (2007). Gamers...in the library?! Chicago: American Library Association.

Neiburger, E., \& Gullett, M. (Winter 2007). Out of the basement: The social side of gaming. Young Adult Library Services, 5(2), 34-38.

Nicholson, S. (2008). Finish your games so you can start your schoolwork: A look at gaming in school libraries. Library Media Connection, 26(5), 52-55.

Pew Internet \& American Life Project (2008). Teens, video games and civics. Washington, DC: Pew Internet \& American Life Project. Retrieved from http://pewinternet.org/ /media//Files/Reports/2008/PIP_Teens_Games_and_Civi cs_Report_FINAL.pdf

Prensky, M. (2006). Don't bother me mom - I'm learning! St. Paul, MN: Paragon House.

Sanford, K. (2008). Videogames in the library? School Libraries Worldwide, 14(2), 8388.

Schaumburg, H. (2001). Fostering girls' computer literacy through laptop learning: Can mobile computers help to level out the gender difference? Building on the Future. Proceedings of the National Educational Computer Conference. June 25-27. 2001, Chicago.

Simpson, E. (2005). Evolution in the classroom: what teachers need to know about the video game generation. TechTrends, 49(5), 17-22.

Squire, K. (2006). From content to context: Videogames as designed experience. Educational Researcher, 35(8), 19-29.

Squire, K., \& Jenkins, H. (2003). Harnessing the power of games in education. Insight, 3, 5-33. 
Tang, S. \& Hanneghan, M. (2011). State of the art model driven game development: A survey of technological solutions for game-based learning. Journal of Interactive Learning Research, 22(4), 551-606.

Taylor, T. (2003, May). Multiple pleasures: Women and online gaming. Convergence, 9, 21-46.

Van Eck, R. (2008). COTS in the Classroom: A teacher's guide to integrating commercial off-the-shelf (COTS) games. In Richard Ferdig (ed) Handbook of Research on Effective Electronic Gaming in Education, Hershey, PA: Idea Group.

Vygotsky, L., \& Luria, A. (1994). Tool and symbol in child development. In R. van der Veer \& J. Valsiner (Eds.), The Vygotsky reader (pp. 99-174). Oxford, UK: Oxford University Press.

\section{Biographical note}

Professor Lesley Farmer coordinates the Librarianship program at California State University Long Beach. She earned her MLS at UNC Chapel Hill and her doctorate at Temple University. In 2011 Dr. Farmer won ALA's Phi Beta Mu Award for library education. Dr. Farmer has worked in school, public, special and academic libraries. She serves as IASL VP Association Relations, IFLA School Libraries Section Editor, and Special Libraries Association Education Division Chair. A frequent presenter and writer for the profession, Dr. Farmer's research interests include digital citizenship, information literacy, assessment, collaboration, and educational technology. 